\title{
Going Primitive: The Ethics of Indigenous Rights Activism in Contemporary Jharkhand
}

Uday Chandra

\section{OpenEdition}

\section{Journals}

\section{Electronic version}

URL: http://journals.openedition.org/samaj/3600

DOI: $10.4000 /$ samaj.3600

ISSN: $1960-6060$

\section{Publisher}

Association pour la recherche sur l'Asie du Sud (ARAS)

\section{Electronic reference}

Uday Chandra, «Going Primitive: The Ethics of Indigenous Rights Activism in Contemporary Jharkhand », South Asia Multidisciplinary Academic Journal [Online], 7 | 2013, Online since 15 October 2013, connection on 01 May 2019. URL : http://journals.openedition.org/samaj/3600 ; DOI : 10.4000/ samaj.3600

This text was automatically generated on 1 May 2019.

\section{$(1) \Theta \Theta$}

This work is licensed under a Creative Commons Attribution-NonCommercial-NoDerivatives 4.0 International License. 


\title{
Going Primitive: The Ethics of Indigenous Rights Activism in Contemporary Jharkhand
}

\author{
Uday Chandra
}

\section{Introduction}

The Aryans came to India from Central Asia. The civilization of Harappa and Mohenjo Daro, which preceded the Aryan invasion, did not have fire altars. Their inhabitants would bury the dead. That is, they were non-Aryans. The Vedas also contain references to this. The war between the gods and the demons is, in fact, the tale of wars against the adivasis. The description of the demons is that of adivasis. The demons were dark and wore horns. Even today, adivasis are swarthy in complexion and they wear horns and dance.

Hitesh Ranjan, ${ }^{1}$ Gandhian activist from Bastar

1 How and why did a labor union organizer from Goa, a former Naxalite student cadre from West Bengal, and a Jesuit priest from Tamil Nadu end up as spokespersons for adivasi rights in contemporary Jharkhand? What caused their political discourse to shift from tribal/adivasi ${ }^{2}$ to indigeneity? Might indigeneity be an ideology for these activists? Might the epigram above be a legitimation tool for this ideology?

To answer these interrelated questions, this paper analyzes the oral histories of three leading indigenous rights activists in Jharkhand, formerly south Bihar. In these selfnarratives, I focus on the ways in which these middle-class ${ }^{3}$ activists have crafted their political ethics with reference to 'indigenous communities' in India and beyond. I argue that 'indigeneity' functions in Jharkhandi activist discourses as a marker of a distinctive 
post-materialist $t^{4}$ turn in bourgeois politics. The defense of the indigenous or primitive speaks to deep-seated existential crises for what I term the 'radical bourgeois self', which seeks to simultaneously transcend the modern domains of state and capital as well as locate an authentic space of political ethics and critique in imagined adivasi collectivities.

The radical bourgeois self may be seen as a Weberian ideal type akin to the 'renouncer' in South Asian civilizations. As Louis Dumont (1986: 25) puts it:

The man who is after ultimate truth forgoes social life and its constraints to devote himself to his own progress and destiny. When he looks back at the social world, he sees it from a distance, as something devoid of reality, and the discovery of the self is for him coterminous, not with salvation in the Christian sense, but with liberation from the fetters of life as commonly experienced in this world.

4 The radical bourgeois self, much like Dumont's renouncer, sacrifices the ordinary householder's existence to pursue a distinctively Indian kind of individualism and freedom. Yet, unlike the renouncer of yore, the radical bourgeois self is a vital part of modern bourgeois society in India. Bourgeois or middle-class society in modern India, even when it is invested in reactionary or racist ideologies, sees itself as 'open-minded and egalitarian', 'fiscally prudent', 'embracing science and rationality', and 'setting aside the primordial ties of caste and kinship'; it has, since the late colonial period, expressed a 'deep ambivalence about popular politics, ....seeking to discipline and mobilize subordinate social groups' even as it sought to be 'an enlightened representative of public opinion' (Baviskar \& Ray 2011: 5-7). The radical bourgeois self largely fits this idealtypical description of middle-class Indian society, but insofar as it draws on an older tradition of world renouncers as radical individualists, it also distinguishes itself as a critic of Indian middle class mores and habits. As member as well as critic, the radical bourgeois self enjoys the privileges of bourgeois citizenship in a deeply hierarchical society even as it defines itself by contrast by pursuing the path of political radicalism. Drawing on the work of Pierre Bourdieu $(1984,1993)$, this paper argues that the radical bourgeois self relies on an exchange of economic capital in the form of material privileges for symbolic capital in the form of status and rank. In other words, what comes across straightforwardly as ascetic renunciation or Marxian 'de-classing' may, in fact, be a matter of striving for sociocultural distinction in the modern bourgeois 'field' in India today. This is hardly a new phenomenon in modern India: the 'ascetic masculinity' of well-known historical figures from Vivekananda to Gandhi has defined radical bourgeois selves in precisely the manner I suggest for indigeneity activists in contemporary Jharkhand (Chakraborty 2011).

5 As indigeneity activists who act as patrons of 'primitive' peoples, ${ }^{5}$ who purportedly avoid lying, the state, and the money economy, radical bourgeois selves assume vanguardist roles in ways that satisfy, firstly, the bourgeois critique of electoral democracy in postMandal India (Corbridge \& Harriss 2000, Deshpande 2003), and, secondly, the postNaxalbari desire for an independent left outside the existing communist party alternatives ${ }^{6}$ (Sitapati 2011). These twin sources of the Jharkhand activist's self may be often complementary, but, at the same time, there are very real tensions between them. As the three activist tales ${ }^{7}$ in this paper demonstrate, independent left activists, for example, often takes bourgeois politics in contemporary India as their ideological point of departure; the bourgeois celebration of the individual is, similarly, at odds with the leftist quest for post-capitalist collectivities. Nonetheless, these tensions come to the fore most clearly when we consider the limited popular support enjoyed by these activists, 
especially when ordinary adivasi men and women refuse to assume what Michel RolphTrouillot (2003) famously called the 'savage slot'.

6 This kind of rejection, in fact, further fuels the existential crises that propel indigeneity activism in Jharkhand today insofar as it prompts the unending bourgeois search for a 'purer', more ethical self that claims to be the antithesis of politics yet, paradoxically, aspires to a total politics that suffuses every individual belief, act, and idiosyncrasy. In invoking 'total politics', I draw on the philosopher Carl Schmitt's (2007) notion of 'the political' as an all-encompassing sphere of human existence that incorporates the economic, social, religious and other spheres. This notion of the 'political', for the indigeneity activists, stands in contrast to the rough and tumble of democratic 'politics' (Marchart 2007: 35-60). In this sense, their quest for the radical bourgeois self is strikingly akin to that of theorists of the 'political' from Schmitt to Laclau (Laclau 2005, Mouffe 2006). This paper thus sheds light not only on the process of making radical bourgeois selves, but also on the politics of the apparently anti-political and anti-modern in contemporary India.

\section{From Goa to Gua: a labor activist's tale}

Oscar Fernandes was born in 1951 in what he calls a 'Roman Catholic ghetto' in a working-class Mumbai neighborhood. Although he firmly believes that the Church was 'linked with modernism and capitalism' worldwide and 'alienate[d] him from [his] cultural roots' in India, he also thinks it played an immense role in shaping him as a young man insofar as the idea of social justice...in theory, if not in practice, entered into [his] mind' through Christian theological teachings. Arguably, what made his middle-class Goan family different was that his father stood as an exception to the usual 'Christian trend to be mere servants of imperialism' by teaching adult working-class men to read and write every evening. When Oscar was four or five years old in the mid-1950s, he, too, would sit with the workers and 'learn A, B, C.' It struck him then that 'people much older than [him] were struggling to learn the language as much as [he] did'. This, he adds, led to 'a profound realization that there were many in society who were less privileged than [him]' and whose intellectual capacities had been 'stunted' due to the 'violent workings of a hierarchical society such as India'. The importance of this episode and the awareness it spawned, Oscar explains, 'only became clear to [him] much later in life, after forty years of work as an activist'.

Such clarity is, of course, apparent only in retrospect, and is commonplace in the construction of autobiographical memory or discourse. We may justifiably ask here why Oscar began his tale from the very beginning of his life. One explanation is that this is a standard genre of autobiography narrated along a linear calendrical notion of time (Freeman 1998, Brockmeier 1995). However, another explanation, by no means incompatible with the first, is that this is a narrative that Oscar has crafted carefully after sustained reflection over various episodes of his life (Singer and Blagov 2004). As Jens Brockmeier (2000: 51) puts it:

[...] autobiographical discourse is the form par excellence in which we give shape to the time of our life-and this, I believe, can be said equally from a narrative, philosophical, psychological, and anthropological point of view. 

discourse must be linked to a more radical constructionist notion of the self itself. In the words of Jerome Bruner (1987: 31):

The ways of telling and the ways of conceptualizing that go with them become so habitual that they finally become recipes for structuring experience itself, for laying down routes into memory, for not only guiding the life narrative up to the present but directing it into the future.... life as led is inseparable from a life as told-or more bluntly, a life is not 'how it was' but how it is interpreted and reinterpreted, told and retold.

In other words, Oscar's calendrical ordering of autobiographical time is inseparable from his ongoing process of self-making as an activist. In this, as we shall see later, he is far more exceptional. Indeed, my argument in this paper is that the Jharkhandi indigeneity activist's self-narrative is a kind of autobiographical discourse that accompanies a particular process of making and remaking the radical bourgeois self in postcolonial India.

11 To return to Oscar's tale, he discusses his desperate need as a young man to break out of his bourgeois background. 'Most Goan Christians in Bombay had limited aspirations: to be a steno[grapher]-typist, secretary, railway clerk and so on'. Oscar did not want to fit the mold and though he got better-paying jobs in IBM and Larsen \& Toubro, he says he chose not to work for those companies. He adds, 'I would try very hard not to get selected during the interview process, but I always ended up with a job offer'. There is more than a hint of bravado here: Oscar believes he was good enough for the jobs that his middle-class peers in Bombay craved for in the 1960s, but he chose not to go their way. This is a heroic self-narrative that valorizes denial rather than conventional notions of achievement. Denial as a way to stymy the bourgeois self does not, however, imply Gandhian-style ascetic masculinity (Alter 2000, see Chakraborty 2011) for Oscar. Ascetic self-denial, whether Gandhian or otherwise, is, for him, merely a kind of puritanism that is essentially about sexual repression. He explains: 'The puritanical ideal, so popular among Indian Christians, ingrains the thought that we don't have any genitals, babies come from heaven, and any sexual feelings are sinful'. In 1969, therefore, at the height of the Naxalite movement, Oscar went to St. Joseph's College in Bangalore. In this part of the self-narrative, calendrical time has been clearly abandoned: job offers precede college, which Oscar presents as the avenue for breaking free from his Christian bourgeois background.

12 College, in Oscar's self-narrative, is where the radical self gets forged after leaving behind its bourgeois baggage. In college, he found 'a group of seniors who were already reading about Marxism and communism'. For someone raised Catholic in postcolonial India, 'praying for people suffering persecution in communist countries', talking about Marx, Mao, Vietnam, and Charu Mazumdar was 'liberating'. These seniors were from Christian backgrounds too, and brought in some amount of moral [or] ethical elements into debates'. Their first challenge, as individuals and as a group, was to accept that 'only five per cent of India consisted of graduates then' and that 'the country spent one lakh rupees to educate each of them'. Whereas the typical bourgeois citizen would have moved on to a job after college, Oscar and his comrades hesitated. He received 'an opportunity to go to XLRI (Xaviers Labor Relations Institute in Jamshedpur) to study labor relations'. This was appealing because, as he says, 'labor studies was exactly what [he] wanted to do'. But then he 'got to know that studying labor relations actually meant learning about how to 
control labor'. In other words, 'joining XLRI would make [him] into a dalaal [broker or pimp] basically'. Around the same time, Oscar joined the All India Catholic University Federation (AICUF), a nationwide network of progressive Catholic students seeking social change. As its national secretary, Oscar had a 'full-time job headquartered in Madras', but he also 'got a chance to travel all around the country, organizing training programmes and getting to see the real India'. This is how he first came to Jharkhand, then south Bihar, and became acquainted with adivasi youth activists in Chaibasa. The upshot was, in his words, that '[his] worldview completely changed'. The radical self had, by now, well and truly taken shape.

13 After a brief stint on scholarship to study Marxism in France, Oscar returned to India at the height of the Emergency declared by Indira Gandhi in 1975-77. When he came to learn his comrades at Chaibasa had been arrested by the Bihar government for participating in the JP movement, he 'went there and never left Jharkhand for the next thirty years'. Oscar explains that '[he] did not know a single word of Hindi then, leave alone Ho'. Nonetheless, he campaigned with other activists for their release, and wrote in local newspapers to rally support for their cause. Learning Hindi was, seemingly, a by-product of this process. Eventually, the Emergency ended, and the adivasi activists were released. From 1978 onwards, the Chaibasa troupe, including Oscar, took up issues concerning Ho workers in the Gua, Noamundi and Chidiya mines of Singhbhum district. Initially, Oscar stayed in a village deep inside the Saranda forest named Koda (name changed) and "learned the Ho language and culture, trying to understand their ways of life and approach to the world'. He tried to instruct them in the essentials of 'Marxist historical materialist thinking'. Pointing to the iron ore mines in the western fringe of Singhbhum, he would tell adivasi workers 'to see how iron and steel made by Tata and others from these mines would create trucks, enriches mine owners, steel companies, truck owners and so on, and proletarianizes the rest of us'. Oscar then adds, with a twist of irony: 'Five or six, I was able to indoctrinate...[guffaws]...and they were able to spread my Marxist message'.

Thereafter, Oscar's radical activist self, having shaken off its bourgeois moorings, was now beginning to see the limitations of 'Marxism in translation' in India (Kaviraj 2009). By the time of the infamous Gua massacre on 8 September 1980, when a band of peaceful adivasi demonstrators were fired upon by the Bihar Military Police in the mining town, Oscar was firmly behind the adivasi mine workers in Singhbhum. When leftists from Calcutta assailed him for limiting himself to adivasi labor problems in the mines, they told him 'that to bring in the revolution, [he] needed to go to Jamshedpur [the location of Tata Iron and Steel Company (TISCO)], where the labor was better developed'. What, he wondered, did it mean for labor to be 'better developed'? Also, 'if only the most developed labor could be revolutionary, then why didn't the revolution begin in Detroit?' These questions made him question the 'elite vanguardism of the Calcutta dadas and their brand of Marxism'. The dadas gave them 'plans to surround Chaibasa town after building bases around the mines in Saranda forest and other stupid stuff. Oscar was keener to adapt Marxist theory with the concrete specificities of adivasi struggles in Jharkhand. He pondered the possibility that the ends of Marxism may in fact be to 'remake society as the Hos and other adivasis of Jharkhand had known for millennia'. This was not the 'primitive communism' of classical Marxist theory, but a healthy, ecologically sustainable, postmaterialist vision for the future in India and beyond. 

be seen in this light. 'Indigeneity' here ought to be seen less as a kind of 'identity politics' for subaltern groups as a post-materialist ideological orientation that permits bourgeois activists to articulate a radical vision of the future. This kind of radicalism challenged not only the confident developmentalist idea of progress in Nehruvian India, but also the vanguardism that characterized Indian Marxism in its different avatars. When he was accused by a senior labor leader of 'drinking hanria [rice beer] with adivasis and sleeping with women in the villages', he retorted, 'If you don't have a penis, does that mean others don't have feelings either?' He adds, 'You can't take hanria out of adivasi culture any more than you can take wine out of French culture'. But, Oscar continues:

The comrades don't understand all this. They are in the shoes of books, but we must be in the shoes of the adivasis. It was their mistake, and I hope future activists will realize all this.

After parting ways with his former Marxist comrades, Oscar organized his own unregistered union of adivasi workers, Saranda Theka Mazdoor Sangh ('Saranda Contract Workers' Collective'). They avoided 'all this reservation business that was coming in then' after Prime Minister V.P. Singh's implementation of the Mandal Commission report in 1989. The union was, in his words, 'very successful' in 'implementing minimum wages and maternity, crèche, medical benefits'. But he found that the male adivasi workers wanted to claim all employment benefits for themselves and to keep their wives at home. After this schism, Oscar 'grew tired of union politics', and saw it as 'more of an adivasi issue than anything else'.

By the early 1990s, Oscar had moved out of labor activism and identified increasingly with the cultural politics of the Jharkhand movement. He 'got to know the movement's cultural leadership', and supported their 'homeland movement and their demand for autonomy'. This kind of politics went beyond the basic demand for a separate state of Jharkhand. 'Without political and cultural autonomy for adivasis,' Oscar explains, 'the demand for Jharkhand was pointless'. This is why he refused to side with those who 'got into power politics and became thekedars (contractors), netas (politicians), etc.'. He went on to write one of the earliest manifestoes on indigenous peoples' rights in India, and reflected in a series of popular writings on how indigeneity was a cultural condition as much as a political project. This manifesto, which 'has been translated into German, Spanish, Bangla...many languages', builds on conversations with 'Naga human rights activists in Delhi' as well as 'international recognition for Rigoberta Menchu and the legal battles of Australian aboriginals and Native Americans in the United States and Canada'. In this manner, it has been possible for Oscar to emerge over the past two decades as a 'Jharkhandi activist for adivasi rights', simultaneously criticizing modern bourgeois lifestyles, left activism, and electoral politics in postcolonial India. Indigeneity neatly resolves multiple crises of modernity for the bourgeois self by remaking it as the authentic voice of the 'original inhabitants of India'. This kind of political ventriloquism, anything but rare in South Asia as the epigram of this paper shows, thus becomes the basis for a new bourgeois politics of purity sans the ideological contradictions experienced by older, discarded activist selves. 


\section{Indigeneity as extreme left politics} after the late Ram Dayal Munda. Yet few know about the personal background of this Bengali modhobittyo (middle class) activist from Howrah. He was born into a well-to-do bhadralok family, and was expected to emulate his father and join 'some government service after school'. Public service was an ideal that had remained in his family from the days of the Congress-led nationalist movement, and there seemed no reason why he would abandon it. As a teenager during the late 1960s, however, 'one of [his] uncles [ mamas] became a Naxal [revolutionary left activist inspired by Mao Tse-tung] and started telling [him] about peasant uprisings in northern and other parts of Bengal'. These stories, 'full of bravery and heroism', made him consider joining his mama and becoming a Naxal. When he informed his mother of his intention, she was 'horrified' and 'tried to talk [him] out of it'. At this point, he 'ran away from [his] house' with the help of his mama'.

Initially, Naxalite politics introduced Sourav to a subterranean world of primarily male comradeship that underpinned everyday political thought and action in Calcutta. As Henrike Donner (2009: 332) has argued:

In the Naxal movement, young men formed very strong bonds with comrades their own age, both male and female, but also with older men. Younger activists were often recruited by a teacher or professor, and they turned their back on their families when they entered into close relationships with these figures of authority. These bonds of comradeship within the party were, as she writes elsewhere, shaped by 'the debates and dialectics of a movement largely dominated by middle-class men' (Donner 2011: 26). In Sourav's case, notions of kinship melded rather easily with the affective ties on which the party's underground organization rested, though the latter also served as a substitute for and critique of modhobittyo domestic relationships in Bengali society. What he learned in the movement, he says, 'remained with [him] lifelong'. This was, above all, a 'commitment to truth and justice, even at the cost of death'. Fighting for truth and justice imbued the young Sourav with a deep sense of moral purpose early in his political life. In Donner's (2009: 340) words:

'With reference to the masculinities embodied here, two related traits attributed to Naxalites more generally are highlighted: personal integrity and unpretentious behaviour, an ideal distinctly associated with the morality of these comrades'.

When repressive police actions under the United Front government of West Bengal began in 1970, he 'could not imagine why anyone would not understand his cause' and, in fact, seek to put him and his comrades in jail.

State repression pushed Sourav into the forests of West Midnapore district, where he first encountered adivasi life in the forest villages on the Bengal-Jharkhand border. What he saw as an underground Naxalite-on-the-run astounded him:

These were people who were living without the kind of violence that we were using to bring revolution in mainstream Indian society. They were poor, but they lived with dignity. They did not steal or tell lies. Men and women were equal among the tribals. They respected Nature and all forms of life. Their ways of life were much superior to ours, I thought.

South Asia Multidisciplinary Academic Journal, 7 | 2013 
Cut off from Calcutta bhadralok culture and society for weeks, Sourav tried to understand a lifeworld he had never encountered before. Although he did not learn their language, he spoke to 'the tribals who knew Bengali', and learned their 'histories, legends, religious and cultural values from them'. Sourav, it must be noted, did not have a college degree at this time, because he had left his home abrupt after finishing his schooling. Experiential learning in the forests of Midnapore, therefore, became his 'first lessons in anthropology, history, environmental science, and so much more'. Above all, he says, '[he] was attracted to the tribal's mind and his way of thinking, which was so different from our own'. 'The philosophical question for me even today', he elaborates, 'is what tribals have to teach us modern men and women who have gone so far away from our roots'.

After a couple of years in the Lalgarh area, Sourav moved in with relatives in Ranchi. Here, in the largest urban center in south Bihar, he believed that 'the West Bengal police wouldn't find him and [he] could start a new life'. In Ranchi, he met Nirmal Minz, then principal of Gossner College and the Lutheran Bishop of Ranchi. When Minz heard Sourav's story, he asked him to start teaching at the college immediately. Sourav 'told him that he didn't even have a Bachelor's degree, and did not know any of the books that college students were required to read'. Minz was, however, adamant. 'A man of your experience of the world', he reportedly said, 'can read books with the students and teach them a lot'. Teaching at Gossner College also allowed Sourav to know the primarily Munda student body well. Often, he 'would take trips to their homes in the villages, participate in their traditional ceremonies, [and] learn their culture'. In the villages, he was also 'invited to speak to people about his political experiences, and [he] told them whatever [he] knew then'. At Gossner College, he had also 'started reading Marx and Engels, Lenin, Mao, dependency theory from Latin America', and discussing it with Minz and his students. As he confessed:

'In the Naxalite days, where was the time to read and study for us? We never read Marx or Mao, but simply listened to what the dadas told us they had written about bringing revolution in a backward society'. Rajarshi Dasgupta (2005: 81) has explored, in an earlier period, "how the discourse of revolution and Marxist identity converged with a radical vision of the bhadralok self'. In this sense, Sourav's self-making process shows how modhobittyo Marxism could become the foundations on which an appreciation of adivasi culture and history could develop.

But what kind of radical self would develop remained an open question. Sourav's interactions with two key Munda figures were critical to his subsequent political trajectory. First, he became 'very close to Moses Gudia', a prominent Munda activist from Lohajimi village in Torpa, who founded the radical Birsa Seva Dal (BSD) at the time of the Naxalite movement in neighboring Bihar, Orissa, and West Bengal. Moses 'took pride in being an adivasi' and he believed, like the Naxalites, in the need for subaltern militancy to 'make adivasis heard in mainstream society'. In its heyday, until the Emergency, the young men who formed the BSD picketed shops owned by dikus (undesirable non-tribals), kidnapped the more notorious ones among them, and threatened others with severe consequences when they erred. Sourav never joined the BSD, but his friendship with Moses Gudia acquainted him with the materiality of 'exploitation and loot in tribal areas by traders, timber contractors, industrialists, and [Bihari] politicians'. He began to 'understand the anger that led Moses and others to take a militant approach'. 
27 A second significant influence on Sourav was the arrival of the renowned linguist Ram Dayal Munda after his doctoral research on Mundari in Chicago and a brief teaching stint in Australia. 'Munda ji', explains Sourav, 'brought in the idea of indigenous peoples' rights to us in Jharkhand. He explained how the tribals in America and Australia were using their shared experience of oppression to combat their white rulers'. Sourav wondered whether Munda's intellectual prowess and his later position as Vice-Chancellor, Ranchi University could be used to leverage the cause of indigeneity during the Jharkhand movement in the 1980s and 1990s. Drawing on the 'materialist approach of [his] Marxist days', he focused on 'forests and [the] environment in which Jharkhand's adivasis lived'. If Munda focused on the erosion of tribal languages and cultures, Sourav began 'making a connection between cultural and environmental degradation'. With the 'loss of forests', he explains, 'adivasis' habitats are disappearing and they will soon disappear themselves'. On asking him what he meant by adivasis disappearing, he replied:

They will become proletarianized in the capitalist system. They will become servants in the houses of upper-caste people in Delhi and Bombay. They will not be adivasis anymore. They will be ashamed to call themselves adivasi. Extreme alienation and destruction will follow.

Today, Sourav is able to join hands with comrades in Latin America and Europe to fight for indigenous peoples' rights worldwide.

More than anyone else in contemporary Jharkhand, Sourav has domesticated discourses of indigeneity in the region's political landscape. Indigeneity, for him as for Oscar, is a way to articulate an ecological and cultural politics that is simultaneously grounded in the material realities of Jharkhand and India as well as in solidarity with other indigenous peoples' activism worldwide. 'Indigeneity is like class', Sourav tells me at the end, 'it is a universal concept'. It is, in other words, a language of solidarity across activist networks that opens up new political resources for bourgeois leadership in Jharkhand and other scheduled areas. At the same time, it is also a framework within which the radical bourgeois self can pursue a pure politics without what Sourav calls the 'compromises that politicians and NGO people have to make'. Yet he himself, unlike the other two activists ${ }^{9}$ in this paper, receives international funds from Europe to finance his non-profit organization. Moreover, if 'indigeneity is like class', why not just stick to class? Sourav chuckles and says:

This is what my Marxist friends always say. But I tell them: 'you are wrong. Class analysis always treats adivasis as backward people who need to be modernized into a revolutionary class that will overthrow capitalism. But adivasis are our history and our future'...They remind us of what we have become today, and also what we must to do to live peacefully and sustainably again.

30 In Sourav's view, therefore, indigeneity is farther left than mainstream Marxism, and it is this extreme left ideological position that he has articulated more clearly over his life from the days of the Naxalite movement to his gradual conversion to the cause of indigeneity in Jharkhand.

\section{A pastor to his flocks}

Michael Muthuraman was born to a wealthy Christian upper-caste household in Salem district of northern Tamil Nadu. As 'the youngest of nine children' in the Muthuraman 
household, he was 'much loved and spoilt by everyone'. The family owned 'plenty of land', and it was commonplace to see 'dalit laborers toiling away on the farm'. For Michael, this was jarring because 'it seemed to go completely against Christian teachings'. He says, 'in church, we were told that all men are created equal in the eyes of God, but my family elders were, literally, slave owners in our ancestral village'. Michael was a 'contemplative boy', and he 'did well on exams'. But since he did not wish to remain tied to the land, he joined the Jesuit church to train to become a priest. Michael never tells me what he studied during his Jesuit training or how it shaped him later. His only comment on those formative years was that 'the Jesuits were as conservative as my family, upper caste in their outlook and opposed to any progressive social change'. This comment dovetails nicely with David Mosse's (2012) recent assessment of the conservative, upper-caste character of the Catholic Church in $20^{\text {th }}$ century Tamil Nadu, and how progressive young priests such as Michael were critical to the shift in church politics over the past half century. In sum, it is against his family and church background that we must seek to understand Michael's self-making process.

At the end of his Jesuit training, in the early 1970s, Michael came to a village one hour away from Chaibasa town in Singhbhum district. A Tamil-speaker in an alien land, he struggled at first to cope with the linguistic demands of his pastoral duties. Yet, as a teacher of schoolchildren, he was curious about his wards, 'their cultural backgrounds, their villages'. Over summer vacations, he 'went to their homes in the villages and learned about Ho culture and religion'. The Jesuits, much like the Lutherans and Anglicans in Jharkhand, had made inroads into the Ho community near Chaibasa since the late $19^{\text {th }}$ century, and there existed a significant Ho Christian population in rural Singhbhum. Michael was particularly interested in how Christianity came to be 'inculturated' or adapted by converts to their own cultural sensibilities. ${ }^{10}$ The 'use of sal [ Shorea robusta] leaves' and 'traditional dance' in adivasi Christian rituals fascinated him. He contrasts his interest in adivasi culture with the relative apathy of the 'American and Australian fathers', who 'received large packages from their families with tinned food, chocolates, clothes'. As he learned the Ho language, the distance between him and his superiors and peers grew apace. 'They did not want to learn. They were happy in their own lives. They couldn't understand why I wanted to do all this'.

Michael's rebellion within the church had only just begun. He began 'reading about liberation theology in Latin America, and how the church was working there among indigenous peoples to bring social change'. Around this time, Michael decided to 'take a break' from his pastoral work and 'study human rights and Marxism at ISI (Indian Social Institute), Bangalore'. This move marked the beginning of his new life as a 'defender of human rights in Jharkhand'. This redefinition of the self, against the inherited and imbibed tendencies of family and church, took place vis-à-vis prevailing 'Indian hierarchies' and bourgeois notions of 'self-interest and selfishness'. Returning to southern India after almost a decade, a radicalized Michael came face to face again with upper-caste prejudices within the church. In one instance, he recalls, he complained to his superiors about a Jesuit priest in rural Karnataka, who was also 'the largest landowner in his village', for employing bonded labor on his fields. His superiors did not take kindly to this kind of activism, and he was 'almost asked to leave the church if he wanted to pursue these issues'. After this episode, Michael drifted away from the church and decided to take part in 'the activities of PUCL and the few organizations that worked for human rights then in India'. By the mid-1980s, his estrangement with the Catholic Church 
was complete, and though he 'has not left it formally', he began 'working more outside it than inside'.

Thereafter, 'fighting for the rights of indigenous peoples' seemed a logical step during the Jharkhand movement. Michael acquainted himself with the movement's leaders, especially Ram Dayal Munda, Nirmal Minz, Sourav, and Oscar, and learned the new activist language of indigeneity from them. 'We agreed', he says, 'that adivasi peoples' struggles are not only limited to Jharkhand or India, but global'. Accordingly, he believes that 'their rights can be defended by activists across borders'. In a manner reminiscent of recent scholarship on transnational activism (Keck \& Sikkink 1998, Escobar 2008), Michael explains to me the need for 'all-India and international networks of human rights activists who can publicize and campaign against exploitation and violence directed at marginalized peoples' such as adivasis in India. Since the formation of a separate state of Jharkhand in 2000, Michael has been one of the most visible activists in the state. $\mathrm{He}$ regularly hosts Delhi-based intellectuals and activists such as Arundhati Roy, Harsh Mander, and Gautam Navlakha when they visit Ranchi. Like them, he deploys the language of indigeneity to criticize 'the Indian state and corporations who are dispossessing adivasis of their land today'. Unlike Oscar and Sourav, however, Michael has not turned to indigeneity as an extension of left activism. For him, it is a more straightforward case of 'finding a way to fight against different kinds of oppression, social, economic, and cultural'. It is quite easy, under the circumstances, to mistake Michael for an American-style liberal fighting for civil liberties within a legalistic framework. But, when I say so to him, he laughs and responds:

I would like to change this society and the world root-and-branch. But one has to walk in small steps to achieve large goals. Indigenous peoples are at the bottom of Indian and global society. By making their freedom our cause, we can purify ourselves of the sins we and our ancestors have committed.

This politics of purification is, I argue in this paper, crucial to the making indigeneity activist selves in Jharkhand and beyond. By disavowing their privileges of birth and the ordinary temptations of bourgeois life in this manner, a distinctive kind of 'authentic'11 radical politics emerges outside the ambit of the institutionalized left.

This independent left is, of course, hostile to the postcolonial state and the rough and tumble of modern democratic politics, particularly as these have evolved in India after the Emergency of 1975. Vinay Sitapati (2011: 43) has argued recently, 'civil libertarians on the [independent] left... unite in their suspicion of the State, sympathy for a variety of "consciousness" other than class, and sharp criticism of party Marxism'. Michael, too, seeks such a politics 'untainted by the compromises of electoral politics and catering more directly to contemporary middle class anxieties' (Sitapati 2011: 43). Yet the redemption of the radical bourgeois self in contemporary India sits uneasily with the aspiration for post-materialist adivasi collectives. Consider, for instance, the recent debate on Maoism in India. Michael, like other members of the independent left, ${ }^{12}$ has criticized the Maoists for 'forcing poor adivasis to become foot soldiers in their fight against the state'. This kind of moral-political positioning permits the indigeneity activist, a special sub-type of the independent left in contemporary India, to claim to be authentic voices of adivasis as they criticize both the state and the Maoists for their predatory ways. But the truth is that the imagined adivasi collectives are non-existent: as Michael says himself, 'whether it is politicians, Maoists, NGOs, whoever, the adivasis are now divided and fight each other'. The indigeneity activist thus ends up in an unfortunate 
double bind: seeking a pure, authentic radical self, he-and it is invariably a 'he'liberates himself from the mores of bourgeois society even as his futuristic vision of adivasi collectives crashes and burns around him. 'They must', as Michael notes wistfully in the end, 'liberate themselves'.

\section{Activist simplifications and subaltern rejoinders}

It is commonplace today, following James Scott (1995), to speak of 'state simplifications'. Yet the evidence presented in this essay points to another kind of ideological politics at work in our world, namely, activist simplifications. As we have seen from the selfnarratives of three leading indigeneity activists in contemporary Jharkhand, activist simplifications tend to posit utopian social collectives and visions of the future that serve to justify a particular process of radical bourgeois self-making in postcolonial India. The simplifications, it is asserted in each self-narrative, draw on a lifetime of close observation and activism among those who are being represented. Nonetheless, this kind of heroic representational politics may be confronted, on the one hand, by evidence that 'the local appropriation and experiences of global discourses of indigeneity can maintain a class system that marginalizes the poorest people' in Jharkhand (Shah 2010: 32), and on the other hand, by subaltern rejoinders to radical bourgeois representations of them as noble savages. As I have argued elsewhere (Chandra 2013b: 59), it is 'easy for activists and scholars, forever searching for the coherent primitive subject in modern India, [to] miss out on how...subject communities negotiate their subjecthood'. Despite their best intentions, therefore, indigeneity activists seeking a pure politics, sans the agonizing compromises and contradictions of modern bourgeois existence, may end up as ventriloquists who deny agency and voice to those whose interests they claim to represent (Spivak 1988).

As a consequence, subaltern rejoinders to activist simplifications deserve our attention. In rural Jharkhand, Alpa Shah (2010) has pointed to the ways in which these simplifications in the realm of adivasi ritual life, human-animal relations, and migration are upset by everyday socio-material realities that do not fit the 'savage slot' well. ${ }^{13}$ Additionally, we must now come to terms with adivasi youth critiques of the 'traditional' gerontocratic order, underwritten by the state in alliance with village elders in rural Jharkhand (Chandra 2013b). Yet what is, arguably, most revealing are contemporary adivasi responses to indigeneity per se. Consider, for example, a recent occasion when Subuddhi, a young Ho engineer based in Chaibasa, tagged me and others on an article that he had posted on Facebook by the sociologist B.K. Roy Burman (2009). Roy Burman argues that '[i]t will perhaps be always better to avoid using the...nomenclature 'Adivasi' in the tenors of serious academic discourse when dealing with the notion of indigenous groups in the Indian context'. In response, another young Ho man, who goes by the name 'Roi Raj' on Facebook, wrote:

All indian groups are based on linguistic identity no matter how minor that group is in no of population---each language should be honored in referencing $n$ identifying a race--Hi I am a Munda sounds much better and respectful than hi $\mathrm{i}$ am a tribal adivasi $i$ live in the wilderness with no clothes i have no internet...

When asked about his views, Subuddhi explained himself soon after: 
Uday Chandra well as i know there is no such term Adiwasi or Tribe in our dictionary, these terms are given by some outsiders of our society and we are feeling proud without knowing whats its real meaning.

Ya i am agree what Roi Raj is saying we should call ourselves as I am a Ho---I am a Munda. ...They have termed us as tribes. We have accepted this without questioning and without shame.

The term tribal or tribe is humiliating and insulting. We are not challenging social theories evolved by others. This is nothing but social construction. It seems to be sometimes we so called educated people are merely literate. It is a clear manifestation of mental slavery on our part. How long will it take for us. Or i must assume that we do not want to come out from this psychological slavery (italics added).

I urge the reader to re-read this block quotation, especially the italicized sections. It is as much a critique of 'primitivism' in academic and activist circles, which draws on Roy Burman's own anthropological critique of indigeneity, as it is a critique of those adivasis whose 'mental slavery' causes them to fall prey to a 'social construction' such as tribe or indigeneity. ${ }^{14}$

41 Needless to say, it would surprise Oscar, Sourav, and Michael to know that their reliance on the notions of tribe and indigeneity is 'humiliating and insulting' to young, educated Ho men. Indeed, this surprise is, in and of itself, a measure of the vast political gulf that separates activist simplifications from their subjects of representation. The radical bourgeois self's post-materialist quest for personal authenticity and salvation thus comes directly into conflict with the aspirations and opinions of postcolonial adivasi subjects in Jharkhand today. In this manner, the neat alignment between activist self-making and adivasi futures goes awry. To go beyond Gayatri Spivak's (1988) well-known thesis on representing subalternity, the speaking subaltern rends asunder the web of activist simplifications that entrap him/her and deepen the existential crisis that produced those simplifications in the first place.

However, indigeneity activists' simplifications constitute an ideology that must attempt to explain everything from the vantage point of the radical bourgeois self. So, if my argument is to be taken to its logical conclusion, challenges to activist simplifications, which heighten the crises of the radical bourgeois self, will lead to a renewed commitment to those very simplifications and reinforce the ideological workings of this variety of primitivism. Recall how Oscar's failure at mobilizing an unregistered adivasi mineworkers' union led him to plunge into indigenous politics wholeheartedly. Or how Sourav's commitment to ecological and cultural conservation has redoubled after the Jharkhand movement became, in his words, 'co-opted by the state for its own purposes'. It is, therefore, time for us to now acknowledge the irresoluble tensions between the postmaterialist agendas of indigeneity activists and the 'authentic' victims for whom they speak in contemporary Jharkhand and beyond. After all, 'authenticity is only an issue for those who yearn for it to complete their own imagined loss' (Tsing 1999: 8). Just as Thomas Hobbes wrote in Chapter XI of Leviathan of the 'restless desire of power after power, that ceaseth only in death', we may justifiably speak today of the radical bourgeois quest for ideological purity, inflected here by Christian theological teachings and/or Marxist doctrines, as restless and endless. 


\section{BIBLIOGRAPHY}

Alter, Joseph S. (2000) Gandhi's Body: Sex, Diet and the Politics of Nationalism, Philadelphia: University of Pennsylvania Press.

Baviskar, Amita; Ray, Raka (eds.) (2011) Elite and Everyman: The Cultural Politics of the Indian Middle Classes, New Delhi: Routledge.

Bourdieu, Pierre (1993) The Field of Cultural Production: Essays on Art and Literature, New York: Columbia University Press.

Bourdieu, Pierre (1984) Distinction: A Social Critique of the Judgment of Taste, Cambridge (Mass.): Harvard University Press.

Brockemeier, Jens (1995) 'The Language of Human Temporality: Narrative Schemes and Cultural Meanings of Time', Mind, Culture, and Activity, 2, pp. 102-18.

Brockemeier, Jens (2000) ‘Autobiographical Time’, Narrative Inquiry, 10(1), pp. 51-73.

Brune, Jerome (1987) ‘Life as Narrative’, Social Research, 54(1), pp. 11-32.

Chakraborty, Chandrima (2011) Masculinity, Asceticism, Hinduism: Past and Present Imaginings of India, Ranikhet: Permanent Black.

Chandra, Uday (2013a) 'Liberalism and its Other: The Politics of Primitivism in Colonial and Postcolonial Indian Law', Law \& Society Review, 47(1), pp. 135-68.

Chandra, Uday (2013b) 'Beyond Subalternity: Land, Community, and the State in Contemporary Jharkhand', Contemporary South Asia, 21(1), pp. 52-61.

Corbridge, Stuart \& John Harriss (2000) Reinventing India: Liberalization, Hindu Nationalism, and Popular Democracy, Cambridge: Polity.

Dasgupta, Rajarshi (2005) 'Rhyming Revolution: Marxism and Culture in Colonial Bengal', Studies in History, 21(1), pp. 79-98.

Deshpande, Satish (2003) Contemporary India: A Sociological View, New Delhi: Viking.

Donner, Henrike (2011) 'Radical Masculinity: Morality, Sociality and Relationships through Recollections of Naxalite Activists', Dialectical Anthropology, 33(3), pp. 327-43.

Donner, Henrike (2009) 'Locating Activist Spaces: The Neighbourhood as a Source and Site of Urban Activism in 1970s Calcutta', Cultural Dynamics, 23(1), pp. 21-40.

Doyle, Dennis M. (2012) 'The Concept of Inculturation in Roman Catholicism: A Theological. Consideration', U.S. Catholic Historian, 30(1), pp. 1-13.

Dumont, Louis (1986) Essays on Individualism: Modern Ideology in Anthropological Perspective, Chicago: University of Chicago Press.

Escobar, Arturo (2008) Territories of Difference: Place, Movements, Life, Redes, Durham \& North Carolina: Duke University Press.

Freeman, Mark (1998) 'Mythical Time, Historical Time, and the Narrative Fabric of the Self', Narrative Inquiry, 8(1), pp. 51-76. 
Gellner, David N. (ed.) (2010) Varieties of Activist Experience: Civil Society in South Asia, New Delhi: Sage Publications.

Gellner, David N. (ed.) (2009) Ethnic Activism and Civil Society in South Asia, New Delhi: Sage Publications.

Ghosh, Kaushik (2006) The Modernity of Primitive India: Adivasi Ethnicity in Jharkhand and the Formation of a National Modern, Ph.D dissertation, Princeton University.

Golomb, Jacob (1995) In Search of Authenticity: From Kierkegaard to Camus, London: Routledge.

Inglehart, Ronald F. (2008) 'Changing Values among Western Publics from 1970 to 2006', West European Politics, 31(1-2), pp. 130-46.

Kaviraj, Sudipta (2009) 'Marxism in Translation: Critical Reflections on Indian Radical Thought', in Richard Bourke \& Raymond Geuss (eds.), Political Judgment: Essays for John Dunn. Cambridge: Cambridge University Press, pp. 172-200.

Kuper, Adam (1988) The Invention of Primitive Society: Transformations of an Illusion. London: Routledge.

Keck, Margaret E.; Sikkink, Kathryn (1998) Activists Beyond Borders: Advocacy Networks in International Politics. Ithaca, New York: Cornell University Press.

Laclau, Ernesto (2005) On Populist Reason, London: Verso.

Marchart, Oliver (2007) Post-foundational Political Thought: Political Difference in Nancy, Lefort, Badiou and Laclau, Edinburgh: Edinburgh University Press.

Mosse, David (2012) The Saint in the Banyan Tree: Christianity and Caste Society in India, Berkeley: University of California Press.

Mouffe, Chanta (2006) The Return of the Political, London: Verso.

Nigam, Aditya (2010) ‘The Rumour of Maoism,' Seminar 607, URL: http://

www.indiaseminar.com/2010/607/607_aditya_nigam.htm.

Rolph-Trouillot, Michel (2003) 'Anthropology and the Savage Slot: The Poetics and Politics of Otherness', in Global Transformations: Anthropology and the Modern World, New York: Palgrave Macmillan, pp. 7-28.

Roy Burman, B.K. (2009) “Adivasi'-A Contentious Term to Denote Tribes as Indigenous Peoples of India', South Asia Citizens Web (27 July), URL: http://www.sacw.net/article1066.html.

Rycroft, Daniel; Dasgupta, Sangeeta (2011) 'Introduction', The Politics of Belonging in India: Becoming Adivasi, Abingdon and New York: Routledge, pp. 1-14.

Schmitt, Carl (2007) The Concept of the Political, Chicago: University of Chicago Press, [1927].

Scott, James C. (1995) 'State Simplifications: Nature, Space and People', Journal of Political Philosophy, 3(3), pp. 191-233.

Shah, Alpa (2010) In the Shadows of the State: Indigenous Politics, Environmentalism and Insurgency in Jharkhand, India, Durham: Duke University Press.

Shorter, Aylward (1988) Toward a Theology of Inculturation. Maryknoll, NY: Orbis.

Simeon, Dilip (2010) 'Permanent Spring', Seminar 607, URL: http://

www.indiaseminar.com/2010/607/607_dilip_simeon.htm.

Singer, Jefferson A.; Blagov, Pavel (2004) 'The Integrative Function of Narrative Processing: Autobiographical Memory, Self-Defining Memories, and the Life Story of Identity', in Denise R. 
Beike, James M. Lampinen, Douglas A. Behrend (eds.), The Self and Memory: Studies in Self and Identity, New York: Psychology Press, pp. 117-38.

Sitapati, Vinay (2011) ‘What Anna Hazare's Movement and India's New Middle Classes Say about Each Other', Economic and Political Weekly, 46(30), pp. 39-44.

Spivak, Gayatri.C. (1988) ‘Can the Subaltern Speak?', in Cary Nelson and Lawrence Grossberg (eds.), Marxism and the Interpretation of Culture. London: Macmillan, pp. 271-316.

Taylor, Charles (1992) The Ethics of Authenticity. Cambridge, M.A.: Harvard University Press.

Tsing, Anna L. (1999) 'Notes on culture and natural resource management', Berkeley Workshop on Environmental Politics, Working Paper 99-4, URL: http://escholarship.org/uc/item/92f9h7ct.

\section{NOTES}

1. This and every other name in this paper has been changed to protect the identities of my interlocutors. I do not believe that naming them publicly is necessary to articulate my argument here. Moreover, naming them runs the risk of threatening their activist careers, which is, of course, very far from my intentions in writing this paper.

2. In this paper, I use the terms 'tribal' and 'adivasi' interchangeably, but consistently prefer the latter since this is a self-description. For a succinct discussion of the politics of these terms as well as 'indigenous', see Rycroft and Dasgupta 2011.

3. I use 'middle class' and 'bourgeois' as synonyms in this paper. This is not only standard lay usage, as the Oxford English Dictionary explains, but also the academic consensus from the days of Marx and Tocqueville.

4. On post-materialism as a political-cultural tendency among middle classes worldwide to seek fulfillment beyond physical security and basic consumption needs, see Inglehart 2008.

5. On 'primitivism' in Indian law and society, see Chandra 2013a; for a global context, see Kuper 1988.

6. At the same time, much like Narmada anti-dam activists, their 'middle-class leadership [was] packaged into the familiar narrative of sacrifice where a privileged, elite person 'gives up' his or her privileges and goes to awaken and mobilize the oppressed masses. This narrative form has direct continuity with the form of the Indian nationalist biography of the nation's leaders: the unconscious, pre-political phase of life, the coming into awareness and the eventual assumption of leadership in mobilizing the people against the state' (Ghosh 2006: 69).

7. These oral histories were collected by me over several meetings with these and other indigeneity activists in Ranchi. I have chosen three oral histories that, I believe, represent a wide range of activist backgrounds in Jharkhand. Besides, these are the stories of the three bestknown activists who were not born in the state. I have known all of them personally since I began fieldwork in Jharkhand in 2008. Indeed, I have worked-and continue to work-closely with them on a range of political and intellectual matters. When published online, I shall certainly share this critique of their work much as I share my other published articles with them.

8. Ho is the adivasi language spoken in Chaibasa and adjoining parts of what was then a unified Singhbhum district.

9. Of the other two activists, one is a priest and continues to live on church premises, whereas the other writes professionally and applies for domestic and international grants to sustain himself.

10. On 'inculturation', see Shorter 1988 and Doyle 2012. As Pope John Paul II himself put it in the Redemptoris Missio of 1990, inculturation for the Catholic church meant ' $[\mathrm{t}]$ he intimate 
transformation of authentic cultural values through their integration in Christianity and the insertion of Christianity in the various human cultures'.

11. By 'authenticity', I am drawing on European existentialist philosophers' notion of a true inner self that can realize its innate needs and desires by overcoming the sociocultural and historical obstacles placed before it. A politics of purism is necessarily built into the existentialist search for authenticity, and hence, the relationship to indigeneity as the basis for a purer, more ethical politics of the self. On authenticity as a philosophical and ethical ideal, see Taylor 1992 and Golomb 1995.

12. See, for example, Simeon 2010 and Nigam 2010. The latter writes of '[Maoists] vicariously playing out their revolutionary fantasies through the lives of adivasis, while the people actually dying in battle are almost all adivasis'.

13. Alpa Shah (2010) has not, however, identified any indigeneity activists as this paper does. In this sense, the paper may be profitably read as complementing, indeed supporting, the thesis advanced by Shah in her book.

14. It is patronizing to ask, as some readers may, whether these young adivasi men are authentic representatives of their communities. To ask such a question is to yield once again to the dubious politics of authenticity in which indigenous activism is mired. I have, nonetheless, written elsewhere on the wider social context of youth critiques of 'traditional' adivasi society, and how these are silenced or ignored by middle-class academics in India (Chandra 2013b).

\section{ABSTRACTS}

How and why did a labor union organizer from Goa, a former Naxalite student cadre from West Bengal and a Jesuit priest from Tamil Nadu end up as spokespersons for adivasi rights in contemporary Jharkhand? What caused their discourse to shift from tribal/adivasi to indigeneity? Might indigeneity be an ideology for them? To answer these questions, this paper analyzes the oral histories of three leading indigenous rights activists in Jharkhand. In these selfnarratives, I focus on how these middle-class activists have crafted their political ethics with reference to 'indigenous peoples' in India and beyond. I argue that 'indigeneity' functions in Jharkhandi activist discourses as a marker of a distinctive post-materialist turn in bourgeois politics. The defense of the indigenous speaks to deep-seated existential crises for these activists, who seek to transcend the modern domains of state and capital and to locate an authentic space of critique in imagined adivasi collectivities.

\section{INDEX}

Keywords: indigeneity, tribes in India, social activism, cultural capital, bourgeois politics, radical politics 


\section{AUTHOR}

\section{UDAY CHANDRA}

Research Fellow, Max Planck Institute for the Study of Religious and Ethnic Diversity, Göttingen 